\title{
$B$ cell targeting therapies in MS patients during the SARS-CoV-2 pandemic - when immunosuppression meets infection?
}

\author{
Marcin P. Mycko \\ Department of Neurology, Faculty of Medicine, University of Warmia and Mazury in Olsztyn, Olsztyn, Poland
}

\begin{abstract}
Introduction. Research into the mechanisms of autoimmune demyelination have highlighted B cells in this process. Therapies targeting this population were a recent addition to the multiple sclerosis (MS) drugs portfolio. The SARS-CoV-2 pandemic and the risk of severe COVID-19 have challenged the safety of $B$ cell depletion in MS patients.

State of the art. Selective depletion of B cells by monoclonal antibodies as monotherapy in MS has been shown to profoundly suppress disease activity among relapsing-remitting MS patients. Furthermore ocrelizumab, a humanised anti-CD20 monoclonal antibody, was the first licensed therapy in primary progressive MS. Based on the concept of the role of B cells in MS, many therapeutic approaches are emerging as novel ways to treat autoimmune demyelination. However, during the SARS-CoV-2 pandemic, a conservative approach toward limiting immune suppression in MS patients has been proposed.

Clinical implications. Emerging evidence does not support the notion of increased susceptibility among MS patients to the SARS-CoV-2 infection, or any predisposition toward greater severity of COVID-19. This also does not appear to be the case for MS patients undergoing $B$ cell depletion therapies. Thus, any decision to withhold immune suppression in MS patients during the SARS-CoV-2 pandemic is probably incorrect. MS therapeutic decision-making should focus on the danger of poorly controlled autoimmune demyelination rather than perceived risks from COVID-19.
\end{abstract}

Future directions. The current pandemic highlights the need to develop more selective and safer methods of immunomodulation in MS. B cells represent several functionally different populations. Further research into the different role of these cells during autoimmune demyelination should yield better, safer strategies to control the encephalitogenic process.

Key words: multiple sclerosis, B cell, disease modifying treatment, immune suppression, SARS-CoV-2, COVID-19

(Neurol Neurochir Pol 2020; 54 (6): 490-501)

\section{Introduction}

Humanity has faced numerous epidemics over the centuries, and the ability to combat pathogens has been crucial to survival. Therefore, infectious diseases are considered as the main source of evolutionary pressure for species genotype. So, epidemics have resulted in the expansion of alleles providing either protection or tolerance to these diseases. Thus heritable variations that increased the survival rate against deadly infectious agents in past generations have been naturally selected before the hosts had the opportunity to reproduce, and are present in the population today, shaping our phenotype [1].
Selection pressure may have led to the promotion of alleles that are protective against pathogens, but bring with them an unfavourable effect on overall organism health.

A prime example of such an effect is a selection of human population haemoglobin gene variants to prevent severe malaria complications [2]. Although these mutations can cause significant health problems such as sickle cell anaemia, their hosts benefit from a decrease of the severity of Plasmodium infections.

The idea that selection pressure from an infection can shape the genetic landscape of the population, promoting alleles that otherwise present deleterious effects, has been 
used to explain the emergence of autoimmune conditions. It is assumed that an inherited predisposition of the immune system to react overtly may have been beneficial in past generations when facing epidemics, but in modern industrialised environments it promotes autoreactivity. In such conditions, molecular mimicry between a benign pathogen can trigger autoimmune diseases [3]. A hygiene hypothesis postulates that an increased frequency of infections contributes to a decrease in autoimmune and allergic conditions [4]. Conversely, lack of infections renders the immune system prone to attack its own antigens, resulting in autoaggression.

One example of the link between infection resistance and autoimmunity is a finding that a variant gene encoding the cytokine and drug target B-cell activating factor (BAFF) was associated with multiple sclerosis (MS) as well as systemic lupus erythematosus [5]. The autoimmunity-risk allele was associated with upregulated humoural immunity through increased levels of soluble BAFF, B lymphocytes, and immunoglobulins. Population genetic signatures indicated that this autoimmunity variant has been evolutionarily advantageous, probably by augmenting resistance to malaria. Thus, a link between autoimmunity and infection, as well as an inborn programme to combat major epidemics, is being postulated as a major aspect of the genetic predisposition toward autoimmunity including MS.

\section{Autoimmune mechanisms in MS}

MS is a chronic inflammatory and autoimmune demyelinating disease manifested by the impairment of nerve conduction due to the degeneration of neurons and oligodendrocytes in the central nervous system (CNS). It has been convincingly demonstrated that mechanisms leading to MS development depend on an aberrant function of the immune system. A central role in this process has been attributed to the disruption of self-tolerance and the promotion of autoimmune inflammation in the brain and spinal cord [6]. The inflammation is mainly driven by autoreactive $T$ and $B$ lymphocytes, directed at target antigens of myelin and non-myelin proteins presented in the $\mathrm{CNS}$, and mediating tissue injury and its associated myelin and neuronal damage [6].

Both pathogenesis and the course of autoimmune demyelination are clearly influenced by a complex interaction of genetic and environmental factors [7]. With regard to the genetic background of MS, the most important risk factor is the human leukocyte antigen (HLA) DR15 haplotype. Currently more than 200 other genetic variants are known to confer the risk to develop the disease, and their role is probably mediated by immune pathway genes $[8,9]$. In addition to a genetic susceptibility, a number of epigenetic mechanisms operate in MS [10-12]. The fact that most of the genetic predisposition for MS is conferred by the DR15 haplotype supports the role of Thelper cells (Th, CD4+ T cells), since CD4+ T cells recognise antigen in the context of HLA class II molecules $[7,13]$.
Thus, the central event in the pathogenesis of MS is related to the induction and uncontrolled action of the Th cells that recognise and respond to CNS autoantigens [14]. A set of immunodominant peptides have been defined from different myelin proteins (e.g. MBP13-32, MBP111-129, MBP146-170, PLP139-154, MOG1-20 and MOG35-55) that were shown to be able to stimulate a high avidity autoreactive T cells [15]. Well over $80 \%$ of relapsing-remitting MS (RRMS) patients demonstrate an immune response against at least one of these peptides [13]. Nevertheless, the exact nature of the antigen driving the autoimmunity remains unknown. Furthermore, significant crossreactivity and degeneration of the Th cells' antigen-specific responses is a factor complicating disentanglement of the primary stimuli promoting the autoimmune demyelination $[16,17]$. The assumption that $\mathrm{CD} 4+\mathrm{T}$ cells are the main population responsible for initiation of damage in CNS during autoaggressive demyelination was confirmed by numerous studies carried out with murine models of MS, experimental autoimmune encephalomyelitis (EAE) [18]. Mice genetically deficient in the presence of $\mathrm{CD} 4+\mathrm{T}$ cells are completely insusceptible to the active induction of disease. Furthermore, the main mediator of autoimmune demyelination is believed to reside within the Th17 subpopulation of Th lymphocytes. Th17 cells are characterised by interleukin (IL)17A and IL-17F secretion and the expression of transcription factors retinoic acid receptor-related orphan receptor alpha and gamma [19]. Studies conducted on mice with impaired function or the number of Th17 cells showed that these mice were significantly resistant to $\operatorname{EAE}[20,21]$. Autoreactivity to myelin peptides involves high avidity myelin-specific $\mathrm{T}$ cells, which are mostly derived from the memory $\mathrm{T}$ cell pool [22]. Single-cell Th clones from patients with MS show enhanced production of IL-17, granulocyte-macrophage colony-stimulating factor (GM-CSF), or interferon gamma; however, in healthy controls, IL-10 dominated $[23,24]$. Although Th17 cells are considered to be the main population that promotes autoimmune demyelination, it has been demonstrated both in mice and humans that not all Th17 cells induce tissue inflammation and disease (i.e. are 'pathogenic'). Non-pathogenic Th17 cells are important players in the healthy organism, e.g. a Th17 population resides within the gut's immune system in a response to changes of the microflora [25].

The complicated picture of Th subpopulations, and the existence of both pro and anti-immune fractions, are reasons why the translation of the data on the role of Th cells in MS pathogenesis for the treatment of this condition has not been successful so far. Direct depletions of the CD4+ T cells in MS patients have yielded negative clinical results [26, 27]. An IL-17 inhibition attempt in MS was not followed [28]. Antigen-specific approaches are promising, but require a complex set of peptides to encompass a high heterogeneity of HLA and antigens [29]. An efficient and selective way of tackling pathogenic Th17 cells has yet to be established. To date, an alternative approach aimed at the manipulation of 
another MS-driving immune population, B cells, has been demonstrated to be highly efficient in slowing this disease.

\section{Role of $B$ cells in autoimmune demyelination and $\mathrm{B}$ cell targeting therapies in MS}

Aberrant B-cell responses in the CNS are well known to be prominent in MS. The presence of intrathecally synthesised immunoglobulin (Ig) $\mathrm{G}$ in the form of oligoclonal bands in cerebrospinal fluid (CSF) is a biomarker of the disease included in the McDonald diagnostic criteria for MS [30, 31]. Clonally related $\mathrm{B}$ cells have been identified in the blood and CSF of MS patients, suggesting a clonal expansion and diversification in the periphery and within the CNS during this condition. $\mathrm{B}$ cells and plasma cells are present in the meninges in MS patients [32]. The meningeal foci can become organised in lymphoid follicle-like structures which in patients with MS is often associated with a more severe disease course and is more prevalent in progressive types of the disease [33]. Large subpial, cortical MS lesions are also more prevalent in the vicinity of the inflammatory infiltrates in the meninges. Thus, $B$ cells are likely to contribute to more advanced or progressive forms of the condition. Apart from the abnormal secretion of the IgG, B cells are also highly potent antigen-presenting cells, thereby providing an important link between them and Th cells [34]. It has been demonstrated that memory B cells from MS patients stimulate autoreactive T cells with brain-homing properties. Furthermore, B cells have been shown to be able to co-express a novel CNS autoantigen [29]. Overall, B cells represent a crucial population with particular properties to present autoantigen to T cells in MS patients, both within CNS and in the peripheral immune compartments.

$B$ cells are also an important source of many proinflammatory cytokines that are likely to promote autoregressive and encephalitogenic reactions [34, 35]. B cells from patients with MS show increased expression of the immunostimulatory nuclear factor $\mathrm{\kappa B}$ after activation via the $\mathrm{CD} 40$ molecule [36]. IL-15, GM-CSF factor, lymphotoxin- $\alpha$, and tumour necrosis factor (TNF) produced by B cells have been found to contribute to the activation of proinflammatory Th1 and Th17 cells, cytotoxic CD8+ T cells, and myeloid cells $[37,38]$. A proinflammatory, GM-CSF-expressing B cells subset has been found to be increased in frequency and more readily induced in MS patients compared to healthy controls [37]. Subsets of B cells, termed regulatory B cells (Breg cells), that produce immune restricting cytokines e.g. IL-10 and IL-35 have also been reported to be less functional in MS [39].

All this data has fuelled interest into the selective therapeutic manipulation of B cells as a therapy for MS (Table 1). Typically, disease-modifying treatments (DMTs) in MS are classified into two categories: immunomodulators or immunosuppressants. Immunomodulators are medications used to help regulate or normalise the immune system. Immunosuppressive therapies aim to temporarily or permanently alter the body's immune system. These two words are often used synonymously with a distinction that modulation appears less severe, whereas suppression is applied for stronger, immune

Table 1. Main published clinical trials in MS with B cell-directed therapies

\begin{tabular}{|c|c|c|c|c|c|c|}
\hline Trial name & $\begin{array}{l}\text { Compound name, } \\
\text { mode of action }\end{array}$ & Route & Phase & Type of MS & $\begin{array}{l}\text { No. of } \\
\text { patients }\end{array}$ & $\begin{array}{l}\text { Overall clinical } \\
\text { outcome }\end{array}$ \\
\hline HERMES [41] & $\begin{array}{l}\text { rituximab, } \\
\text { anti-CD20 }\end{array}$ & intravenous & 2 & RRMS & 104 & positive \\
\hline OLYMPUS [87] & $\begin{array}{l}\text { rituximab, } \\
\text { anti-CD20 }\end{array}$ & intravenous & $2 / 3$ & PPMS & 439 & negative \\
\hline OPERA I+II [42] & $\begin{array}{l}\text { ocrelizumab, } \\
\text { anti-CD20 humanised }\end{array}$ & intravenous & 3 & RRMS & 1656 & positive \\
\hline ORATORIO [47] & $\begin{array}{c}\text { ocrelizumab, } \\
\text { anti-CD20 humanised }\end{array}$ & intravenous & 3 & PPMS & 732 & positive \\
\hline MIRROR [43] & $\begin{array}{c}\text { ofatumumab } \\
\text { anti-CD20 fully human }\end{array}$ & subcutaneous & 2 & RRMS & 232 & positive \\
\hline NCT02738775 [44] & $\begin{array}{c}\text { ublituximab } \\
\text { anti-CD20 } \\
\text { glycoengineered chimeric }\end{array}$ & intravenous & 2 & RRMS & 232 & positive \\
\hline NCT01585766 [45] & $\begin{array}{c}\text { inebilizumab, anti-CD19 } \\
\text { glycoengineered } \\
\text { humanised }\end{array}$ & $\begin{array}{l}\text { intravenous or } \\
\text { subcutaneous }\end{array}$ & 1 & RRMS & 28 & positive (safety) \\
\hline ATAMS [46] & $\begin{array}{l}\text { atacicept (TACl-lg), fusion } \\
\text { protein ( } \mathrm{TACl} \text { receptor } \\
\text { and } \mathrm{Fc} \text { domain } \\
\text { of human } \lg \mathrm{G} 1 \text { ) }\end{array}$ & subcutaneous & 2 & RRMS & 255 & $\begin{array}{l}\text { negative; trial } \\
\text { prematurely } \\
\text { terminated }\end{array}$ \\
\hline NCT02975349 [50] & $\begin{array}{l}\text { evobrutinib } \\
\text { oral BTK inhibitor }\end{array}$ & oral & 2 & RRMS & 267 & positive \\
\hline
\end{tabular}


cell-depleting therapies [40]. With regard to the usefulness of B cell manipulation in MS, immunosuppressive B-cell-depleting clinical studies have so far been particularly informative. A successful phase II trial of rituximab, an anti-CD20 chimeric monoclonal antibody, in MS demonstrated this approach to be both feasible and effective [41]. CD20 molecule is expressed on cells of the $\mathrm{B}$ cells lineage from the pre- $\mathrm{B}$ cell to the early plasmablast stage, and anti-CD20 depletion is an efficient and effective tool to remove most of the $B$ cells. A subsequent anti-CD20 antibodies trials has set out to optimise the efficacy and safety of B cell depletion in MS. In order to decrease the antibody response against anti-CD20, a humanised antiCD20 monoclonal antibody, ocrelizumab, was developed and tested in two twin phase III trials, OPERA I and OPERA II [42]. Patients received intravenous ocrelizumab at a dose of $600 \mathrm{mg}$ every 24 weeks, or subcutaneous interferon beta-1a at a dose of $44 \mu \mathrm{g}$ three times weekly for 96 weeks. The primary end point was the annualised relapse rate, which turned out to be lower with ocrelizumab than with interferon beta-1a, both in trial I ( $0.16 v s$ 0.29), and in trial II ( $0.16 v s 0.29)$. The percentage of patients with disability progression confirmed at 12 weeks was significantly lower with ocrelizumab than with interferon beta-1a (9.1\% vs $13.6 \%)$, as was the percentage of patients with disability progression confirmed at 24 weeks $(6.9 \%$ vs $10.5 \%)$. The mean number of gadolinium-enhancing lesions per T1-weighted magnetic resonance scan was 0.02 with ocrelizumab versus 0.29 with interferon beta- $1 \mathrm{a}$ in trial I and 0.02 versus 0.42 in trial II. Moreover, the efficacy and safety of a fully humanised anti-CD20 antibody, ofatumumab, has been evaluated in a phase II MIRROR study in RRMS, which showed suppression of new MRI lesion development while an antibody response against human anti-CD20 antibodies was not seen in treated patients [43]. Two identical phase 3 clinical trials of ofatumumab in RRMS (ASCLEPIOS I+II) are currently in progress. Ublituximab is a novel chimeric glycoengineered IgG1 that binds a unique epitope on CD20 and demonstrates increased binding capacity to CD20. Ublituximab was recently tested in a phase-II, 48-week, placebo-controlled study, which was designed to assess its optimal dose and infusion time in 48 patients with relapsing forms of MS [44]. This trial has shown also positive results of this type of $B$ cell depletion on RRMS course. Two identical phase 3 clinical trials of ofatumumab in RRMS (ULTIMATE) are in progress. Inebilizumab is a monoclonal antibody which targets another $B$ cell specific surface molecule, CD19 [45]. This antibody eliminates B cells, pro-B cells, plasmablasts, and plasma cells and may provide more complete and prolonged $B$ cell depletion. A phase 1 clinical trial of inebilizumab in relapsing MS patients demonstrated an acceptable safety profile and showed a trend in reductions in new/newly enlarging and gadolinium-enhancing lesions [45]. Conversely, a clinical study testing another B-cell-related therapy, atacicept, a fusion protein of transmembrane activator and CAML interactor (TACI) and Fc fragment of IgG, designed to target targets B cells and plasma cells but not memory B cells, has been tested in MS [46]. This trial has resulted in adverse outcomes. Therefore, a functional heterogeneity must exist among B cells, resulting in their capacity to be either pathogenic or protective in MS. In addition to the involvement of $B$ cells in the pathogenesis of relapsing-remitting MS, ocrelizumab has been shown to be efficacious in primary progressive MS (PPMS). In the phase 3 ORATORIO study, PPMS patients received intravenous ocrelizumab $(600 \mathrm{mg})$ or a placebo every 24 weeks for at least 120 weeks and until a pre-specified number of confirmed disability progression events had occurred. The primary endpoint was the percentage of patients with disability progression confirmed at 12 weeks in a time-to-event analysis [47]. The percentage of PPMS patients with 12-week confirmed disability progression was $32.9 \%$ with ocrelizumab, versus $39.3 \%$ with the placebo. The percentage of patients with 24-week confirmed disability progression was $29.6 \%$ with ocrelizumab versus $35.7 \%$ with the placebo. This has been accompanied by a positive effect on the performance of the timed 25-feet walking test as well as favourable changes in MRI parameters [47]. Ocrelizumab was the first drug to be proven to be an effective DMT for PPMS. These studies have demonstrated the role of both systemic and compartmentalised inflammatory processes in MS pathogenesis, suggesting that anti-CD20 therapy may be effective in managing progression independent of focal inflammation.

In order to avoid elimination of all B cells, including pathogenic and non-pathogenic B cells, resulting in unselective immunosuppression and having some adverse effects, targeted B cell tackling approaches are being tested. Bruton's tyrosine kinase (BTK), a member of the Tec family of kinases, transmits signals through a variety of receptors in B cells [48]. BTK inhibitors are currently under investigation as immunomodulators in several types of autoimmune disease, including systemic lupus erythematosus, rheumatoid arthritis, and MS. Evobrutinib is a selective, covalent, oral inhibitor of BTK that blocks B-cell activation and cytokine release and has been shown to inhibit their activation [49].

Recently, the results of a phase 2 trial of evobrutinib (at a dose of $25 \mathrm{mg}$ once daily, $75 \mathrm{mg}$ once daily, or $75 \mathrm{mg}$ twice daily) in relapsing MS patients versus open-label dimethyl fumarate (DMF) or placebo as a reference have been published [50]. The primary endpoint was the total (cumulative) number of gadolinium-enhancing lesions identified on T1-weighted magnetic resonance imaging at weeks $12,16,20$, and 24. Patients with relapsing MS who received $75 \mathrm{mg}$ of evobrutinib once daily had significantly fewer enhancing lesions during weeks 12 through to 24 than those who received a placebo. There was no significant difference with placebo for either the 25-mg once-daily or 75-mg twice-daily dose of evobrutinib, nor in the annualised relapse rate or disability progression at any dose [50]. A phase $2 \mathrm{~b}$ clinical trial with another BTK inhibitor, SAR442168, in relapsing MS patients has been recently announced to significantly reduce disease activity as measured by MRI [51]. Thus, BTK inhibitors may provide 
efficient therapeutic intervention in MS, expanding the use of B cell-targeted therapies in this condition (Tab. 1). BTK is also known to function in myeloid cells and its inhibition was demonstrated to inhibit the activation, differentiation, and polarisation of proinflammatory M1 macrophages and their release of cytokines [52]. Therefore, the therapeutic action of BTK inhibitors in MS may extend beyond B cells; further research is required to explore the full immunomodulatory potential of these compounds.

\section{SARS-CoV-2 infection and $B$ cell responses in combatting this infection}

Coronaviruses are a diverse group of single-stranded positive sense RNA viruses with a wide range of vertebrate hosts [53]. Four common coronavirus types (alpha, beta, gamma, and delta) circulate among vertebrates causing gastroenteritis in animals. However, in the past two decades, three highly pathogenic human betacoronaviruses have emerged [54]. These human epidemics were probably a result of a transmission from zoonotic events. In 2002-03, severe acute respiratory syndrome related coronavirus 1 (SARS-CoV-1) infected more than 8,000 people worldwide with a fatality rate of about $10 \%$, followed by Middle East respiratory syndrome-related coronavirus (MERS-CoV), which has infected 2,500 people with a fatality rate of $36 \%$ since 2012 [55]. In December 2019, health authorities in Wuhan, China, identified a series of pneumonia cases caused by a previously unknown betacoronavirus. This new pathogen was called severe acute respiratory syndrome coronavirus-2 (SARS-CoV-2), and the disease has been termed coronavirus disease 2019 (COVID-19). The transmission of SARS-CoV-2 occurs mainly via respiratory droplets, similar to the spread of influenza. The estimated basic reproduction number and serial interval are 2.2 and 5-6 days, respectively, with a doubling in the number of infected subjects every three days. Since those first cases in Wuhan, SARS-CoV-2 has spread rapidly throughout the world; on 11 March, 2020, the World Health Organisation declared the coronavirus outbreak a pandemic. The clinical spectrum of SARS-CoV-2 ranges from asymptomatic disease to mild upper respiratory tract infection symptoms (fever, sore throat, cough, and fatigue) to severe pneumonia with respiratory failure and death [56]. In most of those affected, SARS-CoV-2 infection is non-symptomatic or mild. Epidemiological data shows that young children, including infants who are more susceptible to other infections, have milder symptoms and less severe COVID-19. The elderly and those with co-morbidities (diabetes, obesity, and cardiovascular, respiratory, renal, and lung diseases) are most susceptible to COVID-19 and more likely to suffer from the most severe disease complications [57]. The varying degree of the SARS-CoV-2 infection burden results from the fact that the host's response to a virus is generally not uniform, and infections can induce several different types of reactions
[58]. SARS-CoV-2 infection-triggered reactions are distinct compared to other highly pathogenic coronaviruses and common respiratory viruses. It has been shown recently that SARS-CoV-2 induces low levels of type I and III interferons juxtaposed to elevated chemokines and high expression of IL-6 [56]. This may explain why this infection is particularly prone to induce hyperacute responses and may transit from flu-like symptoms into multi-organ failure.

Reduced innate antiviral defences, coupled with exuberant inflammatory cytokine production, have been proposed as drivers towards an unfavourable course of COVID-19. It has been observed that patients with severe COVID-19, requiring intensive care in hospitals, exhibit higher blood plasma levels of proinflammatory cytokines, including IL-6, IL-2R, IL-8, granulocyte stimulating factor and TNF [58]. IL-6 levels in these patients continue to increase over time and are relatively more elevated in non-survivors than in survivors. Such upregulation of proinflammatory cytokines is a feature of cytokine storm syndrome (CSS). CSS has been known to be induced in SARS-CoV-1 or MERS-CoV infections as well as to be associated with an autoimmune rheumatic disease, or chimeric antigen receptor-T cell (CAR-T cell) therapy [59]. In these cases, uncontrolled inflammation inflicts multi-organ damage leading to organ failure, especially of the cardiac, hepatic and renal systems. CSS also precipitates alveolar inflammation and diffuse alveolar damage impairs the infected lungs' ability to participate in gas exchange, culminating in acute respiratory distress syndrome (ARDS) and necessitating mechanical ventilation [60]. ARDS and multi-organ failure are major causes of fatality during COVID-19. The unpredictable course of infection, as well as the risk of triggering a systematic response, are the reasons for the high concern when dealing with the SARS-CoV-2 pandemic.

We are only just beginning to discover the role of different immune populations in the responses to the SARS-CoV-2 infection. To this end, the role of B cells is being particularly investigated, mainly to understand the role of antibodies production in combatting this virus. Recent reports indicate that neutralising antibodies are present in the sera collected from convalescent COVID-19 patients [61, 62]. Serological analysis revealed that SARS-CoV-2-infected patients develop high titres of binding and neutralising antibody responses several days after the onset of clinical disease. Circulating B cells responsible for the production of these antibodies were not dominated by any particular clone, suggesting a wide activation of anti-novel coronavirus immunoglobulins production [61].

Thus, B cells could be critical in combatting the SARS$\mathrm{CoV}-2$ virus. The development of therapeutic interventions will benefit from a better understanding of the protective $B$ cell responses elicited during infection. However, several $B$ cell-independent mechanisms of novel coronavirus clearance are also in place e.g. through the activation of CD8+ T cells or NK cells and the development of anti-SARS-CoV-2 antibodies may not be required for effective recovery from COVID-19 [63]. 
Proper B cell function is also very important for the effective development of long-term immunological protection following a vaccination [64]. Development of long-term immunological memory relies upon humoural and cellular immune responses. Vaccinations aim to stimulate these responses against pathogens. When stimulated in the presence of their target antigen delivered during vaccination, $\mathrm{B}$ and $\mathrm{T}$ cells clonally expand, with some transforming into memory cells, able to rapidly proliferate and become effector cells upon re-exposure to their target antigen. B cells differentiate into plasma cells that generate initially IgM and then IgG antibodies specific to the vaccine-delivered antigen.

Many candidate SARS-CoV-2 vaccines of different types are rapidly undergoing evaluation in clinical trials. Given the key role of $B$ cells in antibody development, any therapy affecting $B$ cell status and function is expected to affect the humoural responses to a SARS-CoV-2 vaccine. Further studies are warranted to elucidate which $B$ cell factors will be critical for the success of future vaccines against novel coronavirus [65].

\section{COVID-19 in MS patients}

The immune system provides vital defences against viral infections. This has raised concern for people with autoimmunity, including MS, as to whether their immune system is capable of efficient clearing of the novel coronavirus. Moreover, a safety issue has been raised concerning the use of the immunosuppressive and modulatory treatments used in MS in SARS-CoV-2 infection, since immune-compromised people could be more vulnerable to infections. Infections are a particularly important concern during a higher efficacy DMT treatment in MS, as a consequence of their more potent immunosuppressive activities [66, 67].

When COVID-19 first emerged, given the paucity of knowledge surrounding SARS-CoV-2, a conservative primum non nocere approach was recommended when treating MS patients. This included the treatment of MS relapses as well as recommendations for DMT including higher efficacy drugs. MS patients have been considered as being at risk in the context of COVID-19 [68]. The emerging data regarding COVID-19 susceptibility in the MS population is fortunately reassuring. It does not appear that MS patients are more vulnerable to the SARS-CoV-2 infection. A recent multicentre study led by the Italian programme for COVID-19 infection in multiple sclerosis, including 238 symptomatic patients ( 57 had positive RT-PCR) from 38 centres, reported that nearly all patients (96\%) developed a mild disease [69]. Unfortunately, five patients died, all of them with EDSS $\geq 6$. A study describing the experience of an MS centre in Chile included the results of an online questionnaire that included COVID-19-related information [70]. With 280 received responses, $14.6 \%$ reported having flu-like symptoms that might have been suggestive of COVID-19 infection. Eventually, only three cases of MS patients (1.07\%) with confirmed SARS-CoV-2 were reported.
Although these patients were hospitalised, all three have since been discharged home [70]. Another recent questionnaire-based study from Poland presented data on $10 \mathrm{MS}$ patients who tested positive for SARS-CoV-2 [71]. No significant changes in neurological status in the course of primary nervous system disease have been noted.

Overall, there is no evidence that MS patients are more prone to the SARS-CoV-2 infection or are at a higher risk of developing severe COVID-19. Conversely, probably due to a younger age and fewer comorbidities, MS patients are actually more likely to experience no symptoms or only mild signs of this infection.

A central issue for MS patient care during the SARSCoV-2 pandemic is their safety while being treated with every type of available DMT. Firstly, it is important to note that there is no evidence that either immunomodulated or immunosuppressed people are at increased risk of coronavirus infections [72]. With the emergence of reassuring data on MS patients' status during the SARS-CoV-2 pandemic, the initial primum non nocere recommendations are being revised. It is emphasised now that the risks of poorly controlled MS might outweigh the perceived risks from COVID-19 [73, 74]. This results in the gradual evolution of the recommendations for MS treatment during the current pandemic. Therefore, to help individual MS patient decisions, it is crucial to consider the mechanisms of each DMT action, the impact of the treatments on infection-risk, vaccination responses and the mechanisms of pathology and immunity to SARS-CoV-2 [73].

Particular concern was initially attributed to those MS patients undergoing $B$ cell depleted therapies with regard to the risk of an aggressive course of SARS-CoV-2 infection [66]. This was based on the notion that patients with a decreased $\mathrm{B}$ cells number might be more susceptible to COVID-19 complications, since this is an immune population responsible for generating neutralising antibodies. Considering the half-life of the anti- $B$ cell therapies as well as kinetics of the $B$ cells repopulation, it is evident that both rituximab and ocrelizumab cause IgM hypogammaglobulinaemia in some people within a few treatment cycles, and this and IgA and IgG hypogammaglobulinaemia increases with repeated infusions, potentially contributing to infection [75]. Therefore, B cell depletion might result in increased susceptibility to infection. Fortunately, the general risk of infections following B cell depletion therapy in MS patients has been already reported. Data from OPERA I and II shows that pre-existing adaptive immunity was not affected by ocrelizumab treatment [76]. Additionally, in the study which evaluated the immune response to vaccines in patients with relapsing MS (the VELOCE study), although reduced compared to placebo-treated patients, patients treated with ocrelizumab were able to mount immune responses to vaccines and new antigens [77]. The incidence of severe infections from ocrelizumab in clinical trials was very low $(1.3 \%$ for relapsing MS and 6.2\% for primary progressive MS) [78]. Some serious infections occurred, including respiratory viral 
complications, but their incidence was low in clinical trials and extended phases [79]. Clinical trials reported similar incidence of infections between rituximab and placebo (69.6\% and 68.2\% vs $65.3 \%$ and $71.4 \%$ respectively) [80]. The incidence of infections in open-label prospective studies varies widely, ranging from $61.5 \%$ to $8 \%$, however infections are generally mild to moderate [81]. Rituximab decreases immunoglobulins without a clear association with serious infection risk [80]. DMTs-induced B cell inhibition would not influence innate and CD8+ $\mathrm{T}$ cell responses, which allows SARS-CoV-2 elimination [63, 75]. Therefore, existing data does not support the notion that $B$ cell depletion in MS patients with ocrelizumab would be deleterious to the clearance of SARS-CoV-2, nor would prevent resistance to this pathogen. In order to directly deal with the putative risk of COVID-19, recent publications have already directly reported on the fate of MS patients treated with B cell depleting therapies and undergoing SARS-CoV-2 infection (Tab. 2). Reports have described together 262 MS patients with COVID-19 treated with either ocrelizumab $(n=195)$ or rituximab $(n=67)$. These patients were from Europe, the US and Iran. Among reported patients, 46 cases of severe or critical COVID have been identified, with five leading to fatality (1.9\%). One deceased MS patient has been undergoing ocrelizumab treatment, and four were rituximab treated (Tab. 2). Although these studies are observational and could suffer from various shortcomings, they provide direct evidence that anti-CD20 did not seem to have an important role in the risk of infection by SARS-CoV2. Furthermore, there is no evidence presently to suggest a more severe course of COVID-19 in ocrelizumab-treated MS patients. Favourable evolution of COVID-19 has been observed in anti-CD20 treated MS patients regardless of the presence or absence of anti-SARSCoV-2 antibodies, so resolution of the condition could be considered to be independent of humoural immunity [82].

These findings seem to support the notion that B cell depletion DMTs should not be halted in MS patients and can be reasonably continued despite the current danger of SARS$\mathrm{CoV}-2$ infection. Furthermore, emerging data does not support an increased risk of severe outcome associated with any DMT used in MS, which should reinforce the recommendation of not stopping current DMTs and not delaying treatment initiation in patients who have higher disease inflammatory activity, risk of relapse, or subsequent disability [83]. Hopefully longer observations and larger consortia studies will further reinforce this statement.

\section{Future directions}

$\mathrm{B}$ cell targeting therapies are the newest addition to the portfolio of therapeutic strategies for treating MS. Their success has confirmed the role of B cells in MS. B cell depletion was also successful in PPMS and ocrelizumab became the first licensed drug for this condition. Despite recent major advances toward a better understanding of the role of B cells in MS, there is still much to be discovered. The development of more effective and safer therapies directed at B cells should focus on compounds that also target specific plasma cells or do not affect Breg, and depends on enhanced understanding and further research into B cell biology, as well as a better understanding of MS pathogenesis.

The safety of cell depletion or immunosuppression has been a subject of major concern since the dawn of these therapies. This issue became particularly important in the SARSCoV-2 pandemic when global populations are at high risk of exposure to a dangerous pathogen. Fortunately, the available data suggests strongly that the B cell manipulation approach in MS patients can be safe even with exposure to SARS-CoV-2.

A number of additional B cell-targeting monoclonal antibodies such as epratuzumab (anti-CD22, a negative regulator of BCR-derived activation signals), daratumumab (anti-CD38 that depletes plasmablasts and some plasma cells), LTbR-IgG (anti-lymphotoxin beta receptor that would reduce the formation of ectopic germinal centres), NNC1140005 (anti-IL21, an important cytokine for Ab formation), otilimab (anti-GM-CSF that blocks pro-inflammatory myeloid cell response), belimumab and talabumab (anti-BAFF), VAY736 (anti-BAFF receptor), hBCMA-Fc (human BCMA fused to IgG1 Fc), and antibodies to co-stimulatory molecules have been developed, primarily for use in haematology that could potentially be repurposed toward MS treatment. Furthermore, a number of small molecules tackling several different components of $B$ cell signalling are also in development [84]. With increasing evidence for the safety of B cell manipulation, these compounds should address the great interest in the further development toward novel therapies of MS. Recent data indicates that high-efficacy therapies in MS commenced within two years of disease onset are associated with less disability after 6-10 years than when commenced later in the disease course, and B cell targeting compounds are considered high-efficacy approaches $[85,86]$.

Although the SARS-CoV-2 pandemic still poses a major threat, it appears that general paradigms of MS DMT selection should not be sacrificed. It should be noted that novel coronavirus clearance can occur via $\mathrm{B}$ cell-independent mechanisms e.g. through the activation of CD8+ T cells and regardless of the presence of anti-SARS-CoV-2 antibodies [63]. Therefore, $\mathrm{B}$ cell targeting therapies may remain an effective way to treat MS without the burden of the increased susceptibility to novel coronavirus infection.

Hopefully, the emergence of an effective vaccine for novel coronavirus will facilitate eradication of this pathogen. Current DMTs in MS are unlikely to inhibit development of the effective resistance via vaccination, although anti-B cell therapies may reduce its effectiveness $[65,75]$. Novel drugs in MS, including new approaches to tackle B cell function, should be designed to provide more selective and less immunosuppressive compound. Finally, SARS-CoV-2 pandemic health data is important and must be collected to help prepare against and combat future infections in both MS patients and the general population. 
Table 2. Studies reporting COVID-19 in MS patients undergoing B cell-depleting therapies

\begin{tabular}{|c|c|c|c|c|c|}
\hline Study & DMT & $\begin{array}{l}\text { No of treated } \\
\text { MS patients }\end{array}$ & MS type & $\begin{array}{l}\text { COVID-19 symptoms or } \\
\text { severity }\end{array}$ & Outcome \\
\hline Novi et al. [88] & ocrelizumab & 1 & PPMS & high fever and severe cough & $\begin{array}{l}\text { Discharged from hospital to } \\
\text { home-quarantine }\end{array}$ \\
\hline Sormiani et al. [69] & $\begin{array}{l}\text { ocrelizumab } \\
\text { rituximab }\end{array}$ & $\begin{array}{c}26 \\
2\end{array}$ & not specified & $\begin{array}{c}\text { mild in overall in MS group, } \\
\text { severe course in two } \\
\text { ocrelizumab-treated patients } \\
\text { (both relapsing-remitting MS), } \\
\text { severe course and death in } \\
\text { one rituximab-treated patient } \\
\text { (PPMS) }\end{array}$ & $\begin{array}{l}\text { Severe course in two MS } \\
\text { patients treated with } \\
\text { ocrelizumab recovered, death } \\
\text { in one rituximab-treated } \\
\text { patient (PPMS) }\end{array}$ \\
\hline Hughes et al. [89] & ocrelizumab & 100 & $\begin{array}{l}\text { relapsing forms }(30 \%) \\
\text { progressive forms } \\
(15 \%) \text { not specified } \\
(55 \%)\end{array}$ & $\begin{array}{l}\text { asymptomatic/mild/moderate } \\
\qquad(64 \%) \\
\text { severe }(30 \%) \\
\text { critical }(6 \%)\end{array}$ & $\begin{array}{l}\text { either recovered or recovering } \\
\qquad(100 \%)\end{array}$ \\
\hline $\begin{array}{l}\text { Montero-Escribano } \\
\text { et al. [90] }\end{array}$ & $\begin{array}{l}\text { ocrelizumab } \\
\text { rituximab }\end{array}$ & $\begin{array}{l}2 \\
6\end{array}$ & $\begin{array}{l}1 \text { PPMS } \\
1 \text { secondary } \\
\text { progressive MS } \\
4 \text { RRMS } \\
2 \text { PPMS }\end{array}$ & $\begin{array}{l}\text { fever, cough, ageusia, fatigue, } \\
\text { odynophagia, myalgia, } \\
\text { anosmia, gastrointestinal } \\
\text { alterations, dyspnoea, } \\
\text { pneumonia }\end{array}$ & $\begin{array}{c}\text { All cases were relatively } \\
\text { mild and only one required } \\
\text { hospital admission but without } \\
\text { complications }\end{array}$ \\
\hline $\begin{array}{l}\text { Ghajarzadeh et al. } \\
\text { [91] }\end{array}$ & ocrelizumab & 1 & $\begin{array}{l}\text { relapsing-remitting } \\
\text { MS }\end{array}$ & $\begin{array}{l}\text { low-grade fever and mild } \\
\text { dyspnoea }\end{array}$ & $\begin{array}{l}\text { recovered during } \\
\text { home-quarantine }\end{array}$ \\
\hline Wurm et al. [92] & rituximab & 1 & progressive MS & $\begin{array}{l}\text { dry cough, dyspnoea, fatigue, } \\
\text { headache, and nausea }\end{array}$ & $\begin{array}{l}\text { all symptoms resolved after } \\
14 \text { days }\end{array}$ \\
\hline $\begin{array}{l}\text { Meca-Lallana et } \\
\text { al. [82] }\end{array}$ & $\begin{array}{l}\text { ocrelizumab } \\
\text { rituximab }\end{array}$ & $\begin{array}{l}6 \\
1\end{array}$ & $\begin{array}{l}4 \text { RRMS, } 1 \text { PPMS } \\
1 \text { progressive MS }\end{array}$ & $\begin{array}{l}\text { two asymptomatic, two mild, } \\
\text { one moderate, one severe }\end{array}$ & $\begin{array}{l}\text { asymptomatic or recovered } \\
\text { completely }\end{array}$ \\
\hline Louapre et al. [93] & ocrelizumab & 1 & SPMS & mild inflammatory syndrome & $\begin{array}{l}\text { At } 14 \text { days post-COVID-19 } \\
\text { diagnosis remained } \\
\text { asymptomatic }\end{array}$ \\
\hline Parotta et al. [94] & $\begin{array}{l}\text { ocrelizumab } \\
\text { rituximab }\end{array}$ & $\begin{array}{l}16 \\
18\end{array}$ & not specified & $\begin{array}{c}\text { nine hospitalised, } 25 \text { non- } \\
\text { hospitalised }\end{array}$ & $\begin{array}{l}\text { One rituximab-treated } \\
\text { RRMS patient deceased; one } \\
\text { ocrelizumab-treated SPMS } \\
\text { patient deceased; } 24 \text { patients } \\
\text { recovered }\end{array}$ \\
\hline Safavi et al. [95] & rituximab & 21 & not specified & not specified & all recovered \\
\hline $\begin{array}{l}\text { Suwanwongse and } \\
\text { Shabarek [96] }\end{array}$ & ocrelizumab & 1 & not specified & $\begin{array}{l}\text { dyspnoea, dry cough, nausea, } \\
\text { vomiting, watery diarrhoea }\end{array}$ & $\begin{array}{l}\text { discharged on day } 5 \text { without } \\
\text { complications }\end{array}$ \\
\hline Conte [97] & ocrelizumab & 1 & not specified & $\begin{array}{l}\text { upper respiratory symptoms, } \\
\text { malaise }\end{array}$ & recovered \\
\hline Lucchini et al. [98] & ocrelizumab & 1 & relapsing MS & $\begin{array}{l}\text { fever, productive cough, sore } \\
\text { throat, nasal congestion }\end{array}$ & recovered \\
\hline Louapre et al. [83] & $\begin{array}{l}\text { ocrelizumab } \\
\text { rituximab }\end{array}$ & $\begin{array}{l}38 \\
17\end{array}$ & not specified & $\begin{array}{l}\text { Two severe (grade } 6 \text { out of 7), } \\
\text { remaining milder course } \\
\text { One deceased (grade } 7 \text { out of } 7 \text { ), } \\
\text { one severe (grade } 6 \text { out of } 7 \text { ), } \\
\text { remaining milder course }\end{array}$ & $\begin{array}{l}\text { One MS patient deceased } \\
\text { was rituximab-treated until } \\
18 \text { months before COVID-19 } \\
\text { onset, otherwise no fatalities in } \\
\text { anti-CD20 treated MS patients }\end{array}$ \\
\hline $\begin{array}{l}\text { Rempe Thornton } \\
\text { and Harel [99] }\end{array}$ & ocrelizumab & 1 & RRMS & $\begin{array}{c}\text { mild cough, dyspnoea on } \\
\text { exertion }\end{array}$ & recovered \\
\hline Barzegar et al. [100] & rituximab & 1 confirmed & SPMS & fever, cough, dyspnoea & deceased \\
\hline
\end{tabular}

Conflicts of interest: None.

Funding: Funded by a University of Warmia and Mazury internal grant to M.P.M. and National Science Centre Poland grant 2020/01/0/NZ6/00072 to M.P.M.

Ethical approval: Not necessary for the preparation of this article.

\section{References}

1. Karlsson EK, Kwiatkowski DP, Sabeti PC. Natural selection and infectious disease in human populations. Nat Rev Genet. 2014; 15(6): 379-393, doi: 10.1038/nrg3734, indexed in Pubmed: 24776769. 
2. Casanova JL. Human genetic basis of interindividual variability in the course of infection. Proc Natl Acad Sci U S A. 2015; 112(51): E7118-E7127, doi: 10.1073/pnas.1521644112, indexed in Pubmed: 26621739.

3. Geginat J, Paroni M, Pagani M, et al. The Enigmatic Role of Viruses in Multiple Sclerosis: Molecular Mimicry or Disturbed Immune Surveillance? Trends Immunol. 2017; 38(7): 498-512, doi: 10.1016/j. it.2017.04.006, indexed in Pubmed: 28549714.

4. Bach JF. The hygiene hypothesis in autoimmunity: the role of pathogens and commensals. Nat Rev Immunol. 2018; 18(2): 105-120, doi: 10.1038/nri.2017.111, indexed in Pubmed: 29034905.

5. Steri M, Orrù V, Idda ML, et al. Overexpression of the Cytokine BAFF and Autoimmunity Risk. N Engl J Med. 2017; 376(17): 1615-1626, doi: 10.1056/NEJMoa1610528, indexed in Pubmed: 28445677.

6. Thompson A, Baranzini S, Geurts J, et al. Multiple sclerosis. The Lancet. 2018; 391(10130): 1622-1636, doi: 10.1016/s01406736(18)30481-1.

7. Cotsapas C, Mitrovic M, Cotsapas C, et al. Multiple sclerosis. Handb Clin Neurol. 2018; 148(6): 723-730, doi: 10.1016/B978-0-44464076-5.00046-6, indexed in Pubmed: 29478610.

8. International Multiple Sclerosis Genetics Consortium. Multiple sclerosis genomic map implicates peripheral immune cells and microglia in susceptibility. Science. 2019; 365(6460), doi: 10.1126/science. aav7188, indexed in Pubmed: 31604244.

9. Mechelli R, Umeton R, Policano C, et al. International Multiple Sclerosis Genetics Consortium, Wellcome Trust Case Control Consortium,2. A "candidate-interactome" aggregate analysis of genome-wide association data in multiple sclerosis. PLoS One. 2013; 8(5): e63300, doi: 10.1371/journal.pone.0063300, indexed in Pubmed: 23696811.

10. Zurawska A, Mycko MP, Selmaj KW. Circular RNAs as a novel layer of regulatory mechanism in multiple sclerosis. J Neuroimmunol. 2019; 334: 576971, doi: 10.1016/j.jneuroim.2019.576971, indexed in Pubmed: 31163273.

11. Mycko MP, Baranzini SE. microRNA and exosome profiling in multiple sclerosis. Mult Scler. 2020; 26(5): 599-604, doi: 10.1177/1352458519879303, indexed in Pubmed: 31965891.

12. Cwiklinska H, Cichalewska-Studzinska M, Selmaj KW, et al. The Heat Shock Protein HSP70 Promotes Th17 Genes' Expression via Specific Regulation of microRNA. Int J Mol Sci. 2020; 21(8), doi: 10.3390/ ijms21082823, indexed in Pubmed: 32316658.

13. Sospedra M, Martin R. Immunology of Multiple Sclerosis. Semin Neurol. 2016; 36(2): 115-127, doi: 10.1055/s-0036-1579739, indexed in Pubmed: 27116718.

14. Hemmer B, Kerschensteiner M, Korn T. Role of the innate and adaptive immune responses in the course of multiple sclerosis. Lancet Neurol. 2015; 14(4): 406-419, doi: 10.1016/S1474-4422(14)70305-9, indexed in Pubmed: 25792099.

15. Jelcic I, Nimer FAl, Wang J, et al. Memory B Cells Activate Brain-Homing, Autoreactive CD4+ T Cells in Multiple Sclerosis. immuneACCESS. , doi: 10.21417/b7cw5v.

16. Mycko MP, Waldner H, Anderson DE, et al. Cross-reactive TCR responses to self antigens presented by different MHC class II molecules. J Immunol. 2004; 173(3): 1689-1698, doi: 10.4049/jimmunol.173.3.1689, indexed in Pubmed: 15265898.

17. Harkiolaki M, Holmes SL, Svendsen P, et al. T cell-mediated autoimmune disease due to low-affinity crossreactivity to common microbial peptides. Immunity. 2009; 30(3): 348-357, doi: 10.1016/j.immuni.2009.01.009, indexed in Pubmed: 19303388.

18. Glatigny S, Bettelli E. Experimental Autoimmune Encephalomyelitis (EAE) as Animal Models of Multiple Sclerosis (MS). Cold Spring Har- bor Perspectives in Medicine. 2018; 8(11): a028977, doi: 10.1101/ cshperspect.a028977.

19. Burkett PR, Meyer zu Horste G, Kuchroo VK. Pouring fuel on the fire: Th17 cells, the environment, and autoimmunity. J Clin Invest. 2015; 125(6): 2211-2219, doi: 10.1172/JCl78085, indexed in Pubmed: 25961452.

20. Bettelli E, Korn T, Oukka M, et al. Induction and effector functions of TH17 cells. Nature. 2008; 453(7198): 1051-1057, doi: 10.1038/ nature07036.

21. Hiltensperger M, Korn T. The Interleukin (IL)-23/T helper (Th)17 Axis in Experimental Autoimmune Encephalomyelitis and Multiple Sclerosis. Cold Spring Harb Perspect Med. 2018; 8(1), doi: 10.1101/cshperspect.a029637, indexed in Pubmed: 29101111.

22. Bielekova B, Sung MH, Kadom N, et al. Expansion and functional relevance of high-avidity myelin-specific $\mathrm{CD} 4+\mathrm{T}$ cells in multiple sclerosis. J Immunol. 2004; 172(6): 3893-3904, doi: 10.4049/jimmunol.172.6.3893, indexed in Pubmed: 15004197.

23. Cao $\mathrm{Y}$, Goods BA, Raddassi $\mathrm{K}$, et al. Functional inflammatory profiles distinguish myelin-reactive $T$ cells from patients with multiple sclerosis. Sci Transl Med. 2015; 7(287): 287ra74, doi: 10.1126/scitranslmed.aaa8038, indexed in Pubmed: 25972006.

24. Galli E, Hartmann FJ, Schreiner B, et al. GM-CSF and CXCR4 define a T helper cell signature in multiple sclerosis. Nat Med. 2019; 25(8): 1290-1300, doi: 10.1038/s41591-019-0521-4, indexed in Pubmed: 31332391.

25. Lee Y, Collins M, Kuchroo VK. Unexpected targets and triggers of autoimmunity. J Clin Immunol. 2014; 34 Suppl 1: S56-S60, doi: 10.1007/ s10875-014-0040-5, indexed in Pubmed: 24789684.

26. van Oosten BW, Lai M, Hodgkinson S, et al. Treatment of multiple sclerosis with the monoclonal anti-CD4 antibody CM-T412: results of a randomized, double-blind, placebo-controlled, MR-monitored phase II trial. Neurology. 1997; 49(2): 351-357, doi: 10.1212/wnl.49.2.351, indexed in Pubmed: 9270561.

27. van Oosten BW, Lai M, Hodgkinson S, et al. A phase II trial of anti-CD4 antibodies in the treatment of multiple sclerosis. Mult Scler. 1996; 1(6): 339-342, doi: 10.1177/135245859600100611, indexed in Pubmed: 9345413.

28. Havrdová E, Belova A, Goloborodko A, et al. Activity of secukinumab, an anti-IL-17A antibody, on brain lesions in RRMS: results from a randomized, proof-of-concept study. J Neurol. 2016; 263(7): 1287-1295, doi: 10.1007/s00415-016-8128-x, indexed in Pubmed: 27142710.

29. Juryńczyk M, Walczak A, Jurewicz A, et al. Immune regulation of multiple sclerosis by transdermally applied myelin peptides. Ann Neurol. 2010; 68(5): 593-601, doi: 10.1002/ana.22219, indexed in Pubmed: 21031576.

30. Magliozzi R, Cross AH. Can CSF biomarkers predict future MS disease activity and severity? Mult Scler. 2020; 26(5): 582-590, doi: 10.1177/1352458519871818, indexed in Pubmed: 31965889.

31. Hartung HP, Graf J, Aktas 0 , et al. Diagnosis of multiple sclerosis: revisions of the McDonald criteria 2017 - continuity and change. Curr Opin Neurol. 2019; 32(3): 327-337, doi: 10.1097/ WC0.0000000000000699, indexed in Pubmed: 30985371.

32. Eggers EL, Michel BA, Wu H, et al. Clonal relationships of CSF B cells in treatment-naive multiple sclerosis patients. JCl Insight. 2017; 2(22), doi: 10.1172/jci.insight.92724, indexed in Pubmed: 29202449.

33. Hauser SL. The Charcot Lecture | beating MS: a story of B cells, with twists and turns. Mult Scler. 2015; 21(1): 8-21, doi: 10.1177/1352458514561911, indexed in Pubmed: 25480864.

34. Sabatino JJ, Pröbstel AK, Zamvil SS. B cells in autoimmune and neurodegenerative central nervous system diseases. Nat Rev Neurosci. 
2019; 20(12): 728-745, doi: 10.1038/s41583-019-0233-2, indexed in Pubmed: 31712781.

35. Thi Cuc B, Pohar J, Fillatreau S. Understanding regulatory B cells in autoimmune diseases: the case of multiple sclerosis. Curr Opin Immunol. 2019; 61: 26-32, doi: 10.1016/j.coi.2019.07.007, indexed in Pubmed: 31445312.

36. Chen D, Ireland SJ, Remington G, et al. CD40-Mediated NF-kappaB Activation in B Cells Is Increased in Multiple Sclerosis and Modulated by Therapeutics. J Immunol. 2016; 197: 4257-65.

37. Li R, Rezk A, Miyazaki Y, et al. Canadian B cells in MS Team. Proinflammatory GM-CSF-producing B cells in multiple sclerosis and B cell depletion therapy. Sci Transl Med. 2015; 7(310): 310ra166, doi: 10.1126/scitransImed.aab4176, indexed in Pubmed: 26491076.

38. Stein J, Xu Q, Jackson KC, et al. Intrathecal B Cells in MS Have Significantly Greater Lymphangiogenic Potential Compared to B Cells Derived From Non-MS Subjects. Front Neurol. 2018; 9: 554.

39. Giacomini E, Rizzo F, Etna MP, et al. Thymosin- $\alpha 1$ expands deficient IL-10-producing regulatory $\mathrm{B}$ cell subsets in relapsing-remitting multiple sclerosis patients. Mult Scler. 2018; 24(2): 127-139, doi: 10.1177/1352458517695892, indexed in Pubmed: 28273784.

40. Brod SA. In MS: Immunosuppression is passé. Mult Scler Relat Disord. 2020; 40: 101967, doi: 10.1016/j.msard.2020.101967, indexed in Pubmed: 32007655.

41. Hauser SL, Waubant E, Arnold DL, et al. HERMES Trial Group. B-cell depletion with rituximab in relapsing-remitting multiple sclerosis. $\mathrm{N}$ Engl J Med. 2008; 358(7): 676-688, doi: 10.1056/NEJMoa0706383, indexed in Pubmed: 18272891.

42. Hauser SL, Bar-Or A, Comi G, et al. OPERA I and OPERA II Clinical Investigators. Ocrelizumab versus Interferon Beta-1a in Relapsing Multiple Sclerosis. N Engl J Med. 2017; 376(3): 221-234, doi: 10.1056/NEJMoa1601277, indexed in Pubmed: 28002679.

43. Bar-Or A, Grove RA, Tolson JM, et al. Subcutaneous ofatumumab in patients with relapsing-remitting multiple sclerosis: The MIRROR study. Neurology. 2018; 90(20): e1805-e1814, doi: 10.1212/ WNL.0000000000005516, indexed in Pubmed: 29695594.

44. Fox E, Lovett-Racke AE, Gormley M, et al. A phase 2 multicenter study of ublituximab, a novel glycoengineered anti-CD20 monoclonal antibody, in patients with relapsing forms of multiple sclerosis. Mult Scler. 2020 [Epub ahead of print]: 1352458520918375, doi: 10.1177/1352458520918375, indexed in Pubmed: 32351164.

45. Agius MA, Klodowska-Duda G, Maciejowski M, et al. Safety and tolerability of inebilizumab (MEDI-551), an anti-CD19 monoclonal antibody, in patients with relapsing forms of multiple sclerosis: Results from a phase 1 randomised, placebo-controlled, escalating intravenous and subcutaneous dose study. Mult Scler. 2019; 25(2): 235-245, doi: 10.1177/1352458517740641, indexed in Pubmed: 29143550.

46. Kappos L, Hartung HP, Freedman MS, et al. ATAMS Study Group. Atacicept in multiple sclerosis (ATAMS): a randomised, placebo-controlled, double-blind, phase 2 trial. Lancet Neurol. 2014; 13(4): 353-363, doi: 10.1016/S1474-4422(14)70028-6, indexed in Pubmed: 24613349.

47. Montalban X, Hauser SL, Kappos L, et al. ORATORIO Clinical Investigators. Ocrelizumab versus Placebo in Primary Progressive Multiple Sclerosis. N Engl J Med. 2017; 376(3): 209-220, doi: 10.1056/ NEJMoa1606468, indexed in Pubmed: 28002688.

48. Crofford LJ, Nyhoff LE, Sheehan JH, et al. The role of Bruton's tyrosine kinase in autoimmunity and implications for therapy. Expert Rev Clin Immunol. 2016; 12(7): 763-773, doi: 10.1586/1744666X.2016.1152888, indexed in Pubmed: 26864273.
49. Haselmayer P, Camps M, Liu-Bujalski L, et al. Efficacy and Pharmacodynamic Modeling of the BTK Inhibitor Evobrutinib in Autoimmune Disease Models. J Immunol. 2019; 202(10): 2888-2906, doi: 10.4049/jimmunol.1800583, indexed in Pubmed: 30988116.

50. Montalban X, Arnold DL, Weber MS, et al. Evobrutinib Phase 2 Study Group. Placebo-Controlled Trial of an Oral BTK Inhibitor in Multiple Sclerosis. N Engl J Med. 2019; 380(25): 2406-2417, doi: 10.1056/ NEJMoa1901981, indexed in Pubmed: 31075187.

51. https://www.sanofi.com/en/media-room/press-releases/2020/2020-02-06-07-00-00 (Setember 5th, 2020.).

52. Rip J, Van Der Ploeg EK, Hendriks RW, et al. The Role of Bruton's Tyrosine Kinase in Immune Cell Signaling and Systemic Autoimmunity. Crit Rev Immunol. 2018; 38(1): 17-62, doi: 10.1615/CritRevImmunol.2018025184, indexed in Pubmed: 29717662.

53. Cui J, Li F, Shi ZL. Origin and evolution of pathogenic coronaviruses. Nat Rev Microbiol. 2019; 17(3): 181-192, doi: 10.1038/s41579-0180118-9, indexed in Pubmed: 30531947.

54. Amanat F, Krammer F. SARS-CoV-2 Vaccines: Status Report. Immunity. 2020; 52(4): 583-589, doi: 10.1016/j.immuni.2020.03.007, indexed in Pubmed: 32259480.

55. de Wit E, van Doremalen N, Falzarano D, et al. SARS and MERS: recent insights into emerging coronaviruses. Nat Rev Microbiol. 2016; 14(8): 523-534, doi: 10.1038/nrmicro.2016.81, indexed in Pubmed: 27344959.

56. Blanco-Melo D, Nilsson-Payant BE, Liu WC, et al. Imbalanced Host Response to SARS-CoV-2 Drives Development of COVID-19. Cell. 2020; 181(5): 1036-1045.e9, doi: 10.1016/j.cell.2020.04.026, indexed in Pubmed: 32416070.

57. Netea MG, Giamarellos-Bourboulis EJ, Domínguez-Andrés J, et al. Trained Immunity: a Tool for Reducing Susceptibility to and the Severity of SARS-CoV-2 Infection. Cell. 2020; 181(5): 969-977, doi: 10.1016/j. cell.2020.04.042, indexed in Pubmed: 32437659.

58. Tay MZ, Poh CM, Rénia L, et al. The trinity of COVID-19: immunity, inflammation and intervention. Nat Rev Immunol. 2020; 20(6): 363-374, doi: 10.1038/s41577-020-0311-8, indexed in Pubmed: 32346093.

59. Mehta P, McAuley DF, Brown M, et al. HLH Across Speciality Collaboration, UK. COVID-19: consider cytokine storm syndromes and immunosuppression. Lancet. 2020; 395(10229): 1033-1034, doi: 10.1016/ S0140-6736(20)30628-0, indexed in Pubmed: 32192578.

60. Vardhana SA, Wolchok JD. The many faces of the anti-COVID immune response. J Exp Med. 2020; 217(6), doi: 10.1084/jem.20200678, indexed in Pubmed: 32353870.

61. Cao Y, Guo X, Sun W, et al. Potent Neutralizing Antibodies against SARS-CoV-2 Identified by High-Throughput Single-Cell Sequencing of Convalescent Patients' B Cells. Cell. 2020 (182): 73-84 e16.

62. Ni L, Cheng ML, Feng Y, et al. Detection of SARS-CoV-2-Specific Humoral and Cellular Immunity in COVID-19 Convalescent Individuals. Immunity. 2020 (52): 971-977 e3.

63. Vabret N, Britton GJ, Gruber C, et al. Sinai Immunology Review Project. Immunology of COVID-19: Current State of the Science. Immunity. 2020; 52(6): 910-941, doi: 10.1016/j.immuni.2020.05.002, indexed in Pubmed: 32505227.

64. Akkaya M, Kwak K, Pierce SKB. cell memory: building two walls of protection against pathogens. Nat Rev Immunol. 2020; 20: 229-38.

65. Ciotti JR, Valtcheva MV, Cross AH. Effects of MS disease-modifying therapies on responses to vaccinations: A review. Mult Scler Relat Disord. 2020 [Epub ahead of print]; 45: 102439, doi: 10.1016/j. msard.2020.102439, indexed in Pubmed: 32769063. 
66. Willis MD, Robertson NP. Multiple sclerosis and the risk of infection: considerations in the threat of the novel coronavirus, COVID-19/SARS-CoV-2. J Neurol. 2020; 267(5): 1567-1569, doi: 10.1007/s00415020-09822-3, indexed in Pubmed: 32303837.

67. Luna G, Alping P, Burman J, et al. Infection Risks Among Patients With Multiple Sclerosis Treated With Fingolimod, Natalizumab, Rituximab, and Injectable Therapies. JAMA Neurol. 2020; 77(2): 184191, doi: 10.1001/jamaneurol.2019.3365, indexed in Pubmed: 31589278.

68. Hartung HP, Aktas O. COVID-19 and management of neuroimmunological disorders. Nat Rev Neurol. 2020; 16(7): 347-348, doi: 10.1038/ s41582-020-0368-9, indexed in Pubmed: 32444648.

69. Sormani M. An Italian programme for COVID-19 infection in multiple sclerosis. The Lancet Neurology. 2020; 19(6): 481-482, doi: 10.1016/s1474-4422(20)30147-2.

70. Ciampi E, Uribe-San-Martin R, Cárcamo C. COVID-19 pandemic: The experience of a multiple sclerosis centre in Chile. Mult Scler Relat Disord. 2020; 42: 102204, doi: 10.1016/j.msard.2020.102204, indexed in Pubmed: 32570203.

71. Rejdak K, Grieb P. Adamantanes might be protective from COVID-19 in patients with neurological diseases: multiple sclerosis, parkinsonism and cognitive impairment. Mult Scler Relat Disord. 2020; 42: 102163, doi: 10.1016/j.msard.2020.102163, indexed in Pubmed: 32388458.

72. D'Antiga L. Coronaviruses and Immunosuppressed Patients: The Facts During the Third Epidemic. Liver Transpl. 2020; 26(6): 832-834, doi: 10.1002/It.25756, indexed in Pubmed: 32196933.

73. Baker D, Amor S, Kang AS, et al. The underpinning biology relating to multiple sclerosis disease modifying treatments during the COVID-19 pandemic. Mult Scler Relat Disord. 2020; 43: 102174, doi: 10.1016/j. msard.2020.102174, indexed in Pubmed: 32464584.

74. Brownlee W, Bourdette D, Broadley S, et al. Treating multiple sclerosis and neuromyelitis optica spectrum disorder during the COVID-19 pandemic. Neurology. 2020; 94(22): 949-952, doi: 10.1212/ WNL.0000000000009507, indexed in Pubmed: 32241953.

75. Baker D, Roberts CAK, Pryce G, et al. COVID-19 vaccine-readiness for anti-CD20-depleting therapy in autoimmune diseases. Clin Exp Immunol. 2020 [Epub ahead of print], doi: 10.1111/cei.13495, indexed in Pubmed: 32671831.

76. Ziemssen T, Bar-Or A, Arnold DL, et al. P 2 Effect of ocrelizumab on humoral immunity markers in the phase iii, double-blind, double-dummy, IFNß-1a-controlled OPERA I and OPERA II studies. Clinical Neurophysiology. 2017; 128(10): e326-e327, doi: 10.1016/j. clinph.2017.06.081.

77. Stokmaier DWK, Chognot C, et al. Effect of ocrelizumab on vaccine responses in patients with multiple sclerosis. Presented at the American Academy of Neurology Annual Meeting in Los Angeles, CA. AAN Oral Presentation \#S3. 6002; 2018.

78. Hauser SL, Kappos L, Montalban X, et al. Safety of Ocrelizumab in Multiple Sclerosis: Updated Analysis in Patients with Relapsing and Primary progressive Multiple Sclerosis. Multiple Sclerosis and Related Disorders. 2018; 26: 264, doi: 10.1016/j. msard.2018.10.102.

79. Derfuss $T$, Weber M, Hughes R, et al. P36 Serum immunoglobulin levels and risk of serious infections in the pivotal phase III trials of ocrelizumab in multiple sclerosis and their open-label extensions. Clinical Neurophysiology. 2020; 131(4): e196, doi: 10.1016/j. clinph.2019.12.042.
80. Moreno Torres I, García-Merino A. Anti-CD20 monoclonal antibodies in multiple sclerosis. Expert Rev Neurother. 2017; 17(4): 359-371, doi: 10.1080/14737175.2017.1245616, indexed in Pubmed: 27718747.

81. Midaglia L, Mora L, Mulero P, et al. [Rituximab: its efficacy, effectiveness and safety in the treatment of multiple sclerosis]. Rev Neurol. 2018; 66(1): 25-32, indexed in Pubmed: 29251340.

82. Meca-Lallana V, Aguirre C, Cardeñoso L, et al. COVID-19 in 7 multiple sclerosis patients in treatment with ANTI-CD20 therapies. Mult Scler Relat Disord. 2020 [Epub ahead of print]; 44: 102306, doi: 10.1016/j. msard.2020.102306, indexed in Pubmed: 32585617.

83. Louapre C, Collongues N, Stankoff B, et al. Covisep investigators. Clinical Characteristics and Outcomes in Patients With Coronavirus Disease 2019 and Multiple Sclerosis. JAMA Neurol. 2020 [Epub ahead of print], doi: 10.1001/jamaneurol.2020.2581, indexed in Pubmed: 32589189.

84. Milo R, Milo R. Therapeutic strategies targeting B-cells in multiple sclerosis. Autoimmun Rev. 2016; 15(7): 714-718, doi: 10.1016/j. autrev.2016.03.006, indexed in Pubmed: 26970489.

85. He A, Merkel B, Brown JW, et al. MSBase study group. Timing of high-efficacy therapy for multiple sclerosis: a retrospective observational cohort study. Lancet Neurol. 2020; 19(4): 307-316, doi: 10.1016/ S1474-4422(20)30067-3, indexed in Pubmed: 32199096.

86. Harding K, Williams O, Willis M, et al. Clinical Outcomes of Escalation vs Early Intensive Disease-Modifying Therapy in Patients With Multiple Sclerosis. JAMA Neurol. 2019; 76(5): 536-541, doi: 10.1001/jamaneurol.2018.4905, indexed in Pubmed: 30776055.

87. Hawker K, O'Connor P, Freedman MS, et al. OLYMPUS trial group. Rituximab in patients with primary progressive multiple sclerosis: results of a randomized double-blind placebo-controlled multicenter trial. Ann Neurol. 2009; 66(4): 460-471, doi: 10.1002/ana.21867, indexed in Pubmed: 19847908.

88. Novi G, Mikulska M, Briano F, et al. COVID-19 in a MS patient treated with ocrelizumab: does immunosuppression have a protective role? Mult Scler Relat Disord. 2020; 42: 102120, doi: 10.1016/j. msard.2020.102120, indexed in Pubmed: 32315980.

89. Hughes R, Pedotti R, Koendgen H. COVID-19 in persons with multiple sclerosis treated with ocrelizumab - A pharmacovigilance case series. Mult Scler Relat Disord. 2020; 42: 102192, doi: 10.1016/j. msard.2020.102192, indexed in Pubmed: 32570202.

90. Montero-Escribano P, Matías-Guiu J, Gómez-lglesias P, et al. Anti-CD20 and COVID-19 in multiple sclerosis and related disorders: A case series of 60 patients from Madrid, Spain. Mult Scler Relat Disord. 2020; 42: 102185, doi: 10.1016/j.msard.2020.102185, indexed in Pubmed: 32408147.

91. Ghajarzadeh M, Mirmosayyeb 0, Barzegar M, et al. Favorable outcome after COVID-19 infection in a multiple sclerosis patient initiated on ocrelizumab during the pandemic. Mult Scler Relat Disord. 2020; 43: 102222, doi: 10.1016/j.msard.2020.102222, indexed in Pubmed: 32464586.

92. Wurm H, Attfield K, Iversen AK, et al. Recovery from COVID-19 in a B-cell-depleted multiple sclerosis patient. Mult Scler. ; 2020: 1352458520943791.

93. Louapre C, Maillart E, Roux T, et al. Patients with MS treated with immunosuppressive agents: Across the COVID-19 spectrum. Rev Neurol (Paris). 2020; 176(6): 523-525, doi: 10.1016/j.neurol.2020.04.009, indexed in Pubmed: 32362357.

94. Parrotta E, Kister I, Charvet L, et al. COVID-19 outcomes in MS: Observational study of early experience from NYU Multiple Sclerosis Com- 
prehensive Care Center. Neurol Neuroimmunol Neuroinflamm. 2020; 7(5), doi: 10.1212/NXI.00000000000000835, indexed in Pubmed: 32646885.

95. Safavi F, Nourbakhsh B, Azimi AR. B-cell depleting therapies may affect susceptibility to acute respiratory illness among patients with multiple sclerosis during the early COVID-19 epidemic in Iran. Mult Scler Relat Disord. 2020; 43: 102195, doi: 10.1016/j.msard.2020.102195, indexed in Pubmed: 32460086.

96. Suwanwongse K, Shabarek N. Benign course of COVID-19 in a multiple sclerosis patient treated with Ocrelizumab. Mult Scler Relat Disord. 2020; 42: 102201.

97. Conte WL. Attenuation of antibody response to SARS-CoV-2 in a patient on ocrelizumab with hypogammaglobulinemia. Mult Scler Relat Disord. 2020; 44: 102315.
98. Lucchini M, Bianco A, Del Giacomo P, et al. Is serological response to SARS-CoV-2 preserved in MS patients on ocrelizumab treatment? A case report. Mult Scler Relat Disord. 2020 [Epub ahead of print]; 44: 102323, doi: 10.1016/j.msard.2020.102323, indexed in Pubmed: 32593961.

99. Thornton JR, Harel A. Negative SARS-CoV-2 antibody testing following COVID-19 infection in Two MS patients treated with ocrelizumab. Mult Scler Relat Disord. 2020 [Epub ahead of print]; 44: 102341, doi: 10.1016/j.msard.2020.102341, indexed in Pubmed: 32622338.

100. Barzegar M, Mirmosayyeb O, Ghajarzadeh M, et al. Characteristics of COVID-19 disease in multiple sclerosis patients. Mult Scler Relat Disord. 2020 [Epub ahead of print]; 45: 102276, doi: 10.1016/j. msard.2020.102276, indexed in Pubmed: 32652473. 